\title{
A STUDY OF URINARY RIBOFLAVIN EXCRETION IN MAN ${ }^{1}$
}

\author{
By A. E. AXELROD, T. D. SPIES, and C. A. ElVEHJEM \\ WITH THE TECHNICAL ASSISTANCE OF VELMA AXELROD \\ (From the Nutrition Clinic at the Hillman Hospital, Birmingham, Alabama, the Department \\ of Biochemistry, University of Wisconsin, and the Department of \\ Internal Medicine, University of Cincinnati)
}

(Received for publication October 31, 1940)

The occurrence of riboflavin deficiency in man has been described by several investigators ( 1 to $5)$. Since urinary excretion tests have proved to be of considerable value in the diagnosis of thiamin and ascorbic acid deficiencies, the present study was undertaken to determine the value of such tests in the diagnosis of riboflavin deficiency.

A pronounced decrease in the urinary riboflavin excretion has been observed in rats and dogs maintained on riboflavin-low diets $(6,7,8)$. Spies, Bean and Ashe (9) have reported a decrease in the amount of riboflavin present in the urine of pellagrins with riboflavin deficiency, and Emmerie (10) has observed that urinary riboflavin excretion of a subject on a diet restricted in riboflavin was 43 to 60 per cent of that observed when the subject was on a normal diet. Both groups of investigators $(9,10)$ noted that the administration of riboflavin was followed by a rapid excretion of the vitamin in the urine. Neuweiler (11) reported a case of ariboflavinosis in an infant who completely retained large doses of riboflavin.

\section{MATERIAL AND METHODS}

Five patients in the Nutrition Clinic of the Hillman Hospital, Birmingham, Alabama, were chosen for this study. This group (Cases I, II, III, IV and V) consisted of malnourished persons who were suffering from a multiple vitamin deficiency. They were hospitalized throughout the study and were restricted to diets deficient in various members of the vitamin B-complex during the course of the investigation. ${ }^{2}$ Two patients (Cases VI and VII) from the Hillman Hospital were

1 These studies were aided by grants from the John and Mary R. Markle Foundation and the Wisconsin Alumni Research Foundation.

2 The diets employed had the following compositions: $D$ iet $A$. Hominy grits, cornmeal, white flour, sugar, pork fat, sweet potato, cabbage, spinach, furnishing approximately 300 micrograms of riboflavin per 2,000 calories. Diet $B$. Hominy grits, white flour, cornmeal, French bread, Karo syrup, sugar, black-eyed peas, salt pork, lard, tomato juice, furnishing negligible amounts of riboflavin. used as controls and were kept on the regular hospital diet. Case VI was convalescing from a severe burn, and Case VII had recently recovered from an attack of empyema. Both were in a good state of nutrition during the observation period.

Twenty-four-hour urine specimens were collected from each patient in dark bottles containing 1 cc. of glacial acetic acid and a small amount of toluene. The volume was measured and aliquots were brought to $\mathrm{pH} 6.6$ and stored in the refrigerator under toluene. Samples were collected over a period of two to four weeks.

The riboflavin content of the urine was determined by the microbiological method of Snell and Strong (12). The reliability of this method for the determination of both the free and combined forms of riboflavin in a number of biological fluids has been adequately established $(12,13)$. When necessary, the urine was diluted with distilled water in order to adjust the riboflavin content to the correct assay range (approximately 0.1 microgram of riboflavin per $\mathrm{ml}$.). All assays were made at three different levels, each level being run in duplicate. It was found that the sample of urine could be stored in the refrigerator for a period of two weeks with no loss in the riboflavin content.

The "saturation" tests were performed by administering riboflavin through intravenous injection and determining the riboflavin content of the following twentyfour-hour urine specimens. Two hundred micrograms of riboflavin per kilogram of body weight were given to all patients except Case I who received 400 micrograms per kilogram of body weight. In order to study the rapidity with which the riboflavin was excreted after injection, urine specimens were taken at varying intervals in the case of Subjects I, II, III and IV.

\section{RESULTS}

The average daily riboflavin excretion for the patients maintained on the deficient diets was as follows: Case I, 59 micrograms; Case II, $61 \mathrm{mi}-$ crograms; Case III, 58 micrograms ; Case IV, 91 micrograms and Case V, 65 micrograms. The values ranged between 58 and 91 micrograms. The variation from day to day was small. For example, the daily riboflavin excretion of Case I varied from 53 to 69 micrograms over a period of one week. It is evident that the riboflavin ex- 
cretion of these patients was very low and distinctly lower than that of Case VI and VII on the regular hospital diet who excreted 236 and 270 micrograms, respectively. The riboflavin excretions for these normal patients were also somewhat low since Strong et al (14) found the daily riboflavin excretion for twelve normal subjects to range from 477 to 835 micrograms, with an average value of 625 micrograms. The most logical explanation for the rather low values for the two normal cases in this study is that the total food intake of these patients during hospitalization was considerably lower than that of the normal and active individuals studied by Strong et al (14). It is our belief, therefore, that the twenty-fourhour urinary riboflavin excretion values may be used as an indication of the dietary intake of riboflavin. Some idea of the degree of deficiency may be obtained by following the daily excretion of riboflavin for several consecutive days. These results are in agreement with those of Ferrebee (15).

The results of the "saturation" tests are given in Table I. No correlation could be found between the daily urinary excretion of riboflavin and the degree of retention of a given test dose of riboflavin. Thus Case V, excreting 65 micrograms of riboflavin per day before treatment, retained the same percentage of administered riboflavin as did Case VI who was excreting 236 micrograms of riboflavin per day. Similarly, Cases I, II, III and IV, with a very low daily urinary excretion of riboflavin, retained amounts

TABLE I

The effect of a diet low in riboflavin upon the daily urinary excretion of riboflavin and upon the retention of intravenously administered riboflavin

\begin{tabular}{|c|c|c|c|}
\hline Case & $\begin{array}{l}\text { Average daily } \\
\text { excretion of } \\
\text { riboflavin in } \\
\text { the urine }\end{array}$ & $\begin{array}{l}\text { Riboflavin given } \\
\text { by intravenous } \\
\text { injection* }\end{array}$ & $\begin{array}{l}\text { Percentage of the } \\
\text { test dose of } \\
\text { riboflavin excreted } \\
\text { in the urine }\end{array}$ \\
\hline $\begin{array}{c}\text { I } \\
\text { III } \\
\text { IV } \\
\text { V } \\
\text { VI } \\
\text { VII }\end{array}$ & $\begin{array}{c}\text { micrograms } \\
59 \\
61 \\
58 \\
91 \\
65 \\
236 \\
270\end{array}$ & $\begin{array}{c}\text { micrograms } \\
21800 \\
14000 \\
12200 \\
11200 \\
12700 \\
11800\end{array}$ & $\begin{array}{c}\text { per cent } \\
72 \\
51 \\
37 \\
63 \\
10 \\
10\end{array}$ \\
\hline
\end{tabular}

* These amounts of riboflavin are equivalent to $400 \mathrm{mi}$ crograms per kilogram of body weight in Case I and 200 micrograms per kilogram of body weight in the other subjects. of a given test dose of riboflavin which were of the same order as those retained by two normal subjects studied by Strong et al (14).

The rapidity with which riboflavin given by intravenous injection is excreted in the urine is shown in Table II. Thirty to 40 per cent of the administered riboflavin was excreted in the urine within one hour after injection in the three subjects who received 200 micrograms of riboflavin per kilogram of body weight. Forty-two per cent of the injected riboflavin was excreted within three hours in the subject who received 400 micrograms of riboflavin per kilogram of body weight.

TABLE II

The rate of excretion through the urine of intravenously administered riboflavin

\begin{tabular}{|c|c|c|c|c|c|c|c|c|c|c|c|c|}
\hline \multirow{2}{*}{ ह } & \multirow{2}{*}{$\begin{array}{l}\text { Ribo- } \\
\text { flavin } \\
\text { given } \\
\text { by } \\
\text { intre- } \\
\text { venous } \\
\text { injeo- } \\
\text { tion }\end{array}$} & \multicolumn{11}{|c|}{$\begin{array}{c}\text { Miorograms of riboflavin exoreted in the urine within the stated } \\
\text { time intervals following the injeotion" }\end{array}$} \\
\hline & & 15 & 30 & 60 & 2 & 3 & 4 & 5 & 6 & 7 & 8 & 24 \\
\hline & $\begin{array}{l}\text { micro- } \\
\text { grams }\end{array}$ & \multicolumn{3}{|c|}{ minutes } & \multicolumn{8}{|c|}{ hours } \\
\hline $\operatorname{III}_{\text {IV }}^{I}$ & $\begin{array}{l}21800 \dagger \\
14000 \\
12200 \\
11200 t\end{array}$ & 1890 & 1660 & $\begin{array}{l}3980 \\
6240 \\
4110 \\
4400\end{array}$ & \begin{tabular}{|l|} 
\\
4346 \\
5255
\end{tabular} & $\mid \begin{array}{c}9260 \\
6452\end{array}$ & $\begin{array}{l}4369 \\
5903\end{array}$ & $\left|\begin{array}{r}11570 \\
6665\end{array}\right|$ & $\begin{array}{l}4415 \\
6023\end{array}$ & $\begin{array}{r}12350 \\
6773\end{array}$ & $\begin{array}{l}4421 \\
6021\end{array}$ & $\begin{array}{r}13020 \\
7151 \\
4548 \\
6996\end{array}$ \\
\hline
\end{tabular}

* Every value represents the total amount of riboflavin which has been excreted up to the given time following injection.

$\dagger$ Equivalent to $\mathbf{4 0 0}$ micrograms of riboflavin per kilogram of body weight.

† Equivalent to 200 micrograms of riboflavin per kilogram of body weight.

\section{DISCUSSION}

The lack of correlation between the daily urinary excretion of riboflavin and the degree of retention of administered riboflavin makes it evident that the riboflavin "saturation" test, as carried out under our conditions, has but little diagnostic value in subjects with a riboflavin deficiency which is complicated with other vitamin deficiencies.

The results of the "saturation" tests obtained with the human subject are in contrast with those obtained with the dog. An uncomplicated riboflavin deficiency can be produced in the dog and it has been found in this species that the degree of retention of a test dose of riboflavin administered either orally or subcutaneously is a measure of the severity of the riboflavin deficiency (8). 
Therefore, a dog suffering from a riboflavin deficiency retains practically all of the administered riboflavin, while a normal dog excretes a significantly larger percentage of the corresponding dose of riboflavin. The test doses of riboflavin used in the dog experiments were similar to those employed in the human studies. It should be emphasized that the "saturation" tests were performed on dogs with an uncomplicated riboflavin deficiency, while the human subjects in this study were suffering from a multiple vitamin deficiency. Thus further work is indicated in order to evaluate the effect of other nutritional factors upon the retention of a given test dose of riboflavin.

\section{SUMMARY}

1. The daily urinary riboflavin excretion of five patients consuming riboflavin-low diets and two patients on a hospital diet was determined. The results of these cases, together with those studied by Strong et al (14), indicate that there is a marked variation in the daily urinary riboflavin excretion which is correlated with the dietary intake of riboflavin. Thus the determination of the daily urinary riboflavin excretion serves as an aid in judging the degree of riboflavin deficiency.

2. Riboflavin "saturation" tests, employing intravenous injections of 200 and 400 micrograms of riboflavin per kilogram of body weight, were carried out on six subjects. No correlation between the amount of the test dose of riboflavin retained and the daily urinary riboflavin excretion was obtained. Therefore, no diagnostic value could be attached to the "saturation" tests performed on the subjects of this study.

3. The rate of excretion of riboflavin into the urine after injection was determined. A very rapid loss in the urine was observed.

\section{CASE ABSTRACTS}

Case I. A 39-year-old white male had been seen in 1939 with pellagra. When admitted to the hospital April 29,1940 , he complained of burning of the stomach, dizziness, sore lips and tongue, and scaling, red ulcerated skin on hands, forearms and legs. He was chronically addicted to alcohol and his diet at home consisted of fat meat, corn bread, syrup, dried beans and fruit, and a glass of milk per day. His tongue was red at the tip and the skin on his face and neck was rough and pigmented; on his forearms, hands, feet and legs there was a dry, scaly, pigmented dermatitis with ulcerated areas near the center of the lesions. He had tender calves, absent knee jerks and ankle jerks and absent appreciation of vibration below the hips. The diagnosis was multiple deficiency of vitamins of the B-complex, principally nicotinic acid and thiamin. During this investigation his vitamin intake was controlled by Diet $A$.

Case II. A 43-year-old white male was admitted to the hospital because of nervousness and pain in the epigastrium. Symptoms began March, 1940. He became dizzy, had frequent headaches, burning of the eyes, tongue and lips. He had lost his appetite and had alternate constipation and diarrhea. His diet at home consisted of a glass of milk daily, pork, dried fruit and vegetables, white bread, karo and butter. Both the bulbar and tarsal conjunctivae were extremely injected and his eyes watered continuously. His lips and buccal mucous membranes were red. There were superficial, dry ulcerations at the angles of the mouth, and his tongue was red at the tip. There was mild tenderness in the epigastrium, his calves were tender to pressure and his ankle jerks were absent. The diagnosis was multiple deficiency of vitamins of the B-complex, principally nicotinic acid, riboflavin and thiamin. During his hospital stay he was kept on control Diet B.

Case III. A 27-year-old, colored female entered the hospital complaining of sore mouth and pain in the legs of two months' duration. At the beginning of her illness she had had scaly, red dermatitis on her fingers and hands but this had cleared. She had had frequent attacks of diarrhea, vomiting, sleeplessness, nervousness, and burning of the mucous membranes of her mouth. Her diet consisted of dried fruit and vegetables, corn bread, biscuits, fat meat and one egg per day. Her conjunctivae were injected and inflamed; her tongue was slick and red; the mucous membranes at the angles of the mouth showed atrophic changes frequently seen after recently healed cheilosis. The skin of the forearms, hands and fingers were hyperpigmented and rough. Her calves and the soles of her feet were tender; ankle jerks were absent, and the skin of her feet and ankles was hyperesthetic to stroke. The diagnosis was multiple deficiency of vitamins of the B-complex, principally nicotinic acid, thiamin and riboflavin. During this investigation she was maintained on control Diet A.

Case IV. A 53-year-old, white male entered the Hillman Hospital with dermatitis on the arms and hands. He complained of headache, dizziness, ringing in the ears, loss of appetite, and burning and cramping of the legs. He was chronically addicted to alcohol and his usual home diet consisted of three eggs per day, fat meat, dried fruits and vegetables, white bread, butter and desserts. His conjunctivae, particularly on the lower lids, were inflamed and granular in appearance. His tongue was coated, and there were scars surrounded by mild erythema at the angles of the mouth, suggesting healing cheilosis. The skin was red, rough and desquamating. There was a sharp border of demarcation between the 
normal skin and the erythematous dermatitis at the elbows. The diagnosis was multiple deficiency of vitamins of the B-complex, principally nicotinic acid and riboflavin. His vitamin intake was controlled by Diet $A$.

Case $V$. A 35-year-old, white male had had pellagra every spring since 1934 . He entered the hospital with the complaint of weakness, dizziness, sore tongue, burning and watering of the eyes, aching of the legs and burning of the soles of the feet. His grandmother, his mother, uncle, wife and three children had had pellagra. His diet at home consisted of one glass of milk and one egg a day, fat pork, dried fruit and vegetables, potatoes, turnip greens, corn bread and biscuits, sorghum or molasses. His conjunctivae were extremely inflamed. He had severe photophobia and lacrimation. His lips, buccal mucous membranes, palate and tongue were reddened. There were superficial, dirty grey erosions at the angles of the mouth. The skin on the face and neck was hyperpigmented and there were pigmentation and scaling on the dorsal surface of the forearms and hands. The calves of the legs were tender to pressure. Perception of vibration was absent over the malleoli. The diagnosis was multiple deficiency of the vitamins of the B-complex, principally thiamin, nicotinic acid and riboflavin. He was maintained on control Diet B during his hospitalization.

\section{BIBLIOGRAPHY}

1. Sebrell, W. H., and Butler, R. E., Riboflavin deficiency in man (ariboflavinosis). Pub. Health Rep., 1939, 54, 2121.

2. Oden, J. W., Oden, L. H., Jr., and Sebrell, W. H., Report of three cases of ariboflavinosis. Pub. Health Rep., 1939, 54, 790.

3. Sydenstricker, V. P., and others, Riboflavin deficiency in human subjects. J. A. M. A., 1939, 113, 1697.
4. Spies, T. D., Vilter, R. W., and Ashe, W. F., Pellagra, beriberi and riboflavin deficiency in human beings: diagnosis and treatment. J. A. M. A., 1939, 113, 931.

5. Jolliffe, N., Fein, H. D., and Rosenblum, L. A., Riboflavin deficiency in man. New England J. Med., 1939, 221, 921.

6. Vivanco, F., Zur Flavinbilanz im Tierkörper. Naturwissenschaften, 1935, 23, 306.

7. Frazer, H. F., Topping, N. H., and Isbell, H., The bacterial assay of riboflavin in the urine and tissues of normal and depleted dogs and rats. Pub. Health Rep., 1940, 55, 280.

8. Axelrod, A. E., Lipton, M. A., and Elvehjem, C. A., Riboflavin deficiency in the dog. Am. J. Physiol. (In press.)

9. Spies, T. D., Bean, W. B., and Ashe, W. F., Recent advances in the treatment of pellagra and associated deficiencies. Ann. Internal Med., 1939, 12, 1830.

10. Emmerie, A., On the relation between intake and excretion of flavins. Acta brev. Neerland., 1937, 7, 71.

11. Neuweiler, W., Ueber den Flavinstoff wechsel bien Neugeborenen. Ztschr. f. Vitaminforsch., 1937, 6, 316.

12. Snell, E. E., and Strong, F. M., A microbiological assay for riboflavin. Ind. and Eng. Chem., Anal. Ed., 1939, 11, 346.

13. Feeney, R. E., and Strong, F. M., The microbiological determination of riboflavin. J. Biol. Chem. (Proc.), 1940, 133, xxxi.

14. Strong, F. M., Feeney, R. E., Moore, B., and Parsons, H. T. J. Biol. Chem., 1941, 137, 363.

15. Ferrebee, J. W., The urinary excretion of riboflavin. Fluorometric methods for its estimation. J. Clin. Invest., 1940, 19, 251. 